\title{
GIFTS AND AGQUISITIONS
}

From among the gifts and other acquisitions of the Library, we have usually selected for note in this department only a few items which are felt to have special interest, value, or usefulness. Little has been said about the quantities of other gifts which flow steadily into the Library, some of them in sizable lots. While they are not rarities, a great many solid and useful volumes are added to the Library's general collections by way of such gifts.

Recently a group of about 2 Ioo volumes was presented by Mrs. John Kean, of Elizabeth, N.J. A considerable part of these is made up of national and state official publications-e.g., Congressional documents, government reports, etc. There are also long runs of several journals; bound files of the New York Herald for the war years 1914-18 and of the New York Sun for the period of an earlier war, I 898-99; books on finance and agriculture, etc.

One area in which the Library has been well favored by its friends in the past year is that of science, particularly pharmacy, medicine, chemistry, and biology. A major gift, totaling over two thousand bound volumes of journals in these fields was received from the E. R. Squibb \& Sons Division of Mathieson Chemical Corporation. From the New Jersey State Department of Health have come several hundred volumes of other such periodicals. Unbound lots of technical journals have been received at intervals also from Ethicon Sutures Laboratories, Inc., Johns-Manville Research Center, and Metal Thermit Corporation. The University's branch librarieschemistry, micro-biology, and pharmacy-have benefited especially from these gifts.

The law libraries at Newark and Camden have benefited also. Mr. W. L. L. Peltz, of Albany, N.Y., has presented some five hundred volumes of his law library. These are largely texts, journals, and reports, from New York and other states. Additional law books have been made available, through the enterprise of Lt. Warren D. Buchanan, '52, from among the Library of Congress duplicates. These have been added to the law library of the Rutgers College of South Jersey.

To a succession of earlier gifts received over the years, $\mathrm{Mr}$. Hiram E. Deats has added several hundred further periodicals, 
serials, assorted books, and pamphlets. The checking, which is still in progress, reveals a number of publications which had been especially wanted. One of these is an early State Federation of Labor report.

Other lots of varying size have been received: about seven hundred New Jersey state and municipal documents, law books, etc., from Mrs. Jay B. R. Smith; three hundred volumes of general literature from Dean Albert E. Meder, Jr.; another lot of two dozen items from Mr. Fred W. DeVoe; a group of reports, etc., on labor law from the Alexander Feller estate; several hundred volumes of periodicals from Mr. John B. Kaiser for the University's new library school; I 25 volumes in the field of sociology, with nearly all the Russell Sage Foundation publications, from Mr. Henry L. DeForest; a Jules Verne collection and a group of periodicals dealing with magic, from Dr. J. Milton French, presented in behalf of his son, who had assembled them; a group of pamphlets, including two I 8thcentury American juveniles, the gift of Mr. Henry Wilson of Neshanic, presented through Mr. G. Clifford Nevius.

Returning now to rarities, we can report with pleasure a new gift of the Class of I933, from which was received last year the seven-volume collection of Benjamin West material. Another fine gift of the Class is the Microcosm of London, bound in three volumes. This work brought out by the London publisher Rudolph Ackermann, beginning in I 808, appeared in twenty-four parts, containing one hundred superb color plates of Thomas Rowlandson and A. C. Pugin, with accompanying text. The plates depict every end of the London scene, from a session of Parliament to a thronging fish market peopled with the caricatured figures which one associates with Rowlandson's work. The Library has two similarly illustrated Ackermann publications, presented some years ago by the late John Wyckoff Mettler: History of the University of Oxford (2 vols., I 8 I 4) and History of the University of Cambridge (2 vols., I 815), both ascribed to William Combe.

Several other gifts have been received for purchases in restricted fields. From a fund provided by Dr. L. W. Famulener, three volumes of the printed New York Dutch Church marriage and baptismal records ( $1639-1800$ ) have been acquired. Another sum of money has been made available by the New Jersey Society of 
Mayflower Descendants to be used for materials relating to the Massachusetts Bay Colony or Plymouth Colony.

In memory of its late president, Colonel E. W. Palmer, the Kingsport Press has presented to the Library a specially-bound set of Sir Winston S. Churchill's six-volume Second World War ( 1 94853). The binding, finely wrought in gold-tooled scarlet morocco, is the work of a Kingsport Press craftsman.

Certainly the most curious newcomers to the manuscript collection are the records of two pursuing societies: the Aid and Detective Society of Franklin Park (4 vols., I 878-1940) and the Ewing and Hopewell Vigilant Society (4 vols., I 857 -I 946). The former came as a gift of Mr. J. Garretson Cortelyou, obtained for the Library by Mr. G. Clifford Nevius; the latter were presented by Mr. Woodruff Hendrickson, through Mr. Robert L. Scharring-Hausen, 'I6.

For those too young to know, it may be explained that pursuing or vigilant societies were neighborhood organizations of farmers whose purpose was to protect the members against horse-thieves, investigating such thefts, pursuing the miscreants, and recovering the stolen beasts. Reward notices were posted and sometimes, when the sleuthing failed, partial recompense was paid to the losers. A number of pursuing societies existed in the early I 800's, and there were many more by the turn of the century. Their usefulness largely ended when horses gave way to the automobile and tractor. Several moribund societies attempted to face the new condition, and concerned themselves half-heartedly with thieves of a lower order, such as chicken-snatchers. Sentimentalists have even saved a few of these organizations, in New Jersey and elsewhere, which still meet annually and carry on a limited business, but the records of the older societies are the more interesting.

Readers will recall previous references to the West Jersey Proprietors, whose records are being microfilmed by the Library. One member of the Council, which governed that great land-owning body, was George Sykes. Four boxes of his papers have been presented by Mr. and Mr. Walter L. Reeder, to whom they descended. George Sykes (1802-1880) was a Burlington County man, universally respected and frequently called to positions of trust. $\mathrm{He}$ was early drawn into politics and served as a Democrat in Congress from I 843 to I 848 . Notable among the papers are several hundred letters written to him by his political associates and favor-seekers 
in that period, during thirty succeeding years, and finally while he was a member of the state legislature, I 877-79.

During the I 870 's, George O. Vanderbilt was in the legislature too, an ambitious young lawyer barely out of college at the time. The Library has received four boxes of his papers, which reveal him not only as a successful Princeton attorney, but as an enterprising businessman and promoter as well. Vanderbilt was interested in two short-line passenger railways. The papers include records of the Princeton-Trenton Railway Company, I 893-r9oo, and material of or concerning the Trenton, Lakewood and Seacoast Railway Company, I 900-26. Vanderbilt's political successes were widely spaced. His original two terms in the Assembly were of 1874-75, and in I 924 he was back again after fifty years-an uncommon record, no doubt.

Newspapers have reported lately the finding of a mastodon skeleton, finally secured by the State Museum. It is curious to read a letter in which Governor Rodman M. Price wrote, nearly a hundred years earlier, about another mastodon, then newly discovered. Feeling that it should be kept in New Jersey if possible, he urged the state geologist, Dr. William Kitchell, to buy it at any cost-up to fifty dollars, that is. This and other letters of May, I 855 , concerning the skeleton are from three boxes of William Kitchell papers which the Library has just acquired, dating from the late I 840 's through 186I. Dr. Kitchell studied medicine in New York but found the business not to his taste and turned instead to a new science, geology. After further training in Germany, he was appointed in I 854 to head the newly-authorized geological survey of New Jersey. Although the funds gave out prematurely, he persisted until the project was done and the reports had been printed, and then he turned to private work in the same line.

The late Mr. Howard A. Krumwiede, long a friend of the $\mathrm{Li}_{-}$ brary, spent many years assembling a collection of material relating to New Jersey postal history. The result is fourteen albums containing several hundred examples of local post office cancellations in the form of stamped and stampless covers, with meticulous notes and lists, covering in particular detail Middlesex County, but also including other parts of the state as well.

Space does not allow the other manuscript accessions to be dealt with in detail. There have been forty in the past six months, total- 
ing about six thousand pieces. Other donors include Mrs. Asher Atkinson, Mrs. Robert Bonham, Dr. C. R. Davis, '28, Miss Lucy A. Farnam, Mr. Ernest R. Dalton, Mr. G. Clifford Nevius, Dr. H. Clay Reed, Dr. Hubert G. Schmidt, Rev. George B. Scholten, and Mrs. P. N. Snelling.

\section{Exhibitions}

The schedule for the next academic year is as follows:

Sept. I5-Oct. I4 Introduction to Rutgers (for incoming freshmen)

Oct. I 5-Nov. I 5 Politics

Nov. I 5-Dec. 3I Gift books and annuals

Jan. I-3 I Early agriculture

Feb. $I-28$

March I-3 I

April I-30

George Washington

Newspapers

May I-I 4

Medals

May I 5-Sept. I4 American paper money 